University of Nebraska - Lincoln

DigitalCommons@University of Nebraska - Lincoln

Faculty Papers and Publications in Animal

Science

Animal Science Department

January 1987

\title{
EFFECT OF LEVEL OF PROTEIN AND SUPPLEMENTAL CHOLINE ON REPRODUCTIVE PERFORMANCE OF GILTS FED SORGHUM DIETS
}

\author{
C. V. Maxwell \\ Oklahoma Agricultural Experiment Station, Stillwater \\ R. K. Johnson \\ University of Nebraska-Lincoln, rjohnson5@unl.edu \\ W. G. Luce \\ Oklahoma Agricultural Experiment Station, Stillwater
}

Follow this and additional works at: https://digitalcommons.unl.edu/animalscifacpub

Part of the Animal Sciences Commons

\footnotetext{
Maxwell, C. V.; Johnson, R. K.; and Luce, W. G., "EFFECT OF LEVEL OF PROTEIN AND SUPPLEMENTAL CHOLINE ON REPRODUCTIVE PERFORMANCE OF GILTS FED SORGHUM DIETS" (1987). Faculty Papers and Publications in Animal Science. 41.

https://digitalcommons.unl.edu/animalscifacpub/41

This Article is brought to you for free and open access by the Animal Science Department at DigitalCommons@University of Nebraska - Lincoln. It has been accepted for inclusion in Faculty Papers and Publications in Animal Science by an authorized administrator of DigitalCommons@University of Nebraska - Lincoln.
} 


\title{
EFFECT OF LEVEL OF PROTEIN AND SUPPLEMENTAL CHOLINE ON REPRODUCTIVE PERFORMANCE OF GILTS FED SORGHUM DIETS ${ }^{1}$
}

\author{
C. V. Maxwell ${ }^{2}$, R. K. Johnson ${ }^{3}$ and W. G. Luce ${ }^{2}$ \\ Oklahoma Agricultural Experiment Station, Stillwater 74078
}

\begin{abstract}
A total of 214 gilts was used (two trials) to determine the effect of protein level and choline supplementation during gestation on weight gain, conception rate and subsequent reproductive performance. The gilts were fed either a 12 or $16 \%$ crude protein sorghum-soybean meal diet containing either a high supplemental choline level or no supplemental choline in a $2 \times 2$ factorial arrangement of treatments. Conception rate was not influenced by either protein or choline level. Choline supplementation increased pig weight at $42 \mathrm{~d}$ of age $(\mathrm{P}<.14)$ and litter weight at 21 $(\mathrm{P}<.12)$ and $42 \mathrm{~d}(\mathrm{P}<.1)$. Gilts fed the $16 \%$ protein diet produced larger pigs at $42 \mathrm{~d}(\mathrm{P}<.13)$ and heavier litters at birth, $(\mathrm{P}<1) 21 \mathrm{~d}(\mathrm{P}<.14)$ and $42 \mathrm{~d}(\mathrm{P}<.05)$ than gilts fed the $12 \%$ protein diet. A larger choline effect on litter size and pig and litter weight was observed for gilts fed the $12 \%$ protein diet than for those fed the $16 \%$ gestation diet, although the protein-choline interaction was not significant for any traits measured. The incidence of spraddle leg condition was low and was not affected by level of dietary protein or supplemental choline.

(Key Words: Pigs, Choline, Protein Intake, Sorghum, Reproductive Performance.)
\end{abstract}

\section{Introduction}

Several studies have shown that supplemental choline in corn-soybean meal (Kornegay and Meacham, 1973; Stockland and Blaylock, 1974, NCR-42 Committee on Swine Nutrition, 1976) or barley-wheat (Grandhi and Strain, 1981) gestation diets will increase litter size. No research has been reported concerning the need for choline in sorghum-based diets, although sorghum is a major feed ingredient in the southwest.

Because higher amino acid values (NRC, 1979) and higher amino acid digestibilities (Cousins et al., 1981; Easter, 1972) have been reported for corn than for sorghum, energy source may affect the amount of dietary protein needed to meet requirements during gestation. Although many studies have been conducted to determine the effect of dietary protein during gestation on subsequent reproductive performance with corn-based diets

\footnotetext{
${ }^{1}$ Journal article no. 4180 of the Oklahoma Agr. Exp. Sta., Stillwater 74078

${ }^{2}$ Dept. of Anim. Sci.

${ }^{3}$ Present address: Anim. Sci. Dept., Univ of Nebras$\mathrm{ka}$, Lincoln 68583

Received August 29, 1986.

Accepted December 2, 1986.
}

(Baker et al., 1970a,b; Mahan and Mangan, 1975), few studies have been conducted with sorghum-based diets (Haught et al., 1977).

A growth response to supplemental choline has been demonstrated in the young pig fed low protein diets (Kroening and Pond, 1967; Russett et al., 1979a), but not higher protein diets (Bryant et al., 1977; Russett et al., 1979b). The relationship between protein and(or) methionine intake and the choline requirement for the gestating sow has not investigated.

The objective of this study was to determine the effect of level of protein and choline supplementation on the reproductive performance of gestating swine fed sorghum-based diets.

\section{Experimental Procedure}

A total of 214 Hamphshire $\times$ Yorkshire, Duroc $\times$ Yorkshire and Duroc $\times$ Hampshire crossbred gilts was utilized in two trials. In each trial, 14 gilts were assigned randomly to each of eight pens so that there were approximately equal numbers of gilts from each breed group in each pen. Pens were assigned randomly to one of four dietary treatments using a $2 \times 2$ factorial arrangement with two levels of protein and two levels of supplemental choline (table 1). The diet had a sorghum base, and soybean meal was adjusted to give either 12 or $16 \%$ crude protein. Zero vs $882 \mathrm{mg} / \mathrm{kg}$ supplemental 
TABLE 1. COMPOSITION OF EXPERIMENTAL DIETS

\begin{tabular}{|c|c|c|c|c|}
\hline \multirow[b]{2}{*}{ Ingredient, \% } & \multicolumn{4}{|c|}{ Gestation diets } \\
\hline & $\mathbf{A}$ & B & $\mathrm{C}$ & D \\
\hline Milo, ground & 86.31 & 86.31 & 75.17 & 75.17 \\
\hline Soybean meal, $44 \%$ & 10.02 & 10.02 & 21.32 & 21.32 \\
\hline Dicalcium phosphate & 1.66 & 1.66 & 1.42 & 1.42 \\
\hline Calcium carbonate & 1.01 & 1.01 & 1.09 & 1.09 \\
\hline Salt & .50 & .50 & .50 & .50 \\
\hline Vitamin trace mineral mix ${ }^{a}$ & .50 & .50 & .50 & .50 \\
\hline Antibiotic $\operatorname{mix}^{b}$ & .25 & .25 & .25 & .25 \\
\hline Choline (trial 1), mg/kg & & 882 & & 882 \\
\hline Choline (trial 2), mg/kg & & 551 & & 551 \\
\hline Crude protein, $\%$ & 12 & 12 & 16 & 16 \\
\hline
\end{tabular}

${ }^{\mathrm{a}}$ Vitamin-trace mineral premix supplied $660,000 \mathrm{IU}$ vitamin $\mathrm{A}, 66,000 \mathrm{IU}$ vitamin $\mathrm{D}_{3}, 1,320 \mathrm{IU}$ vitamin $\mathrm{E}$, $440 \mathrm{mg}$ menadione sodium bisulfite, $880 \mathrm{mg}$ riboflavin, $6.6 \mathrm{~g}$ niacin, $4.4 \mathrm{~g}$ pantothenic acid, $3.3 \mathrm{mg}$ vitamin $B_{12}$, $44 \mathrm{mg} 1,19.8 \mathrm{~g} \mathrm{Fe}, 4.4 \mathrm{~g} \mathrm{Mn}, 2.2 \mathrm{~g} \mathrm{Cu}$ and $19.8 \mathrm{~g} \mathrm{Zn}$ per $\mathrm{kg}$ of premix.

$\mathrm{b}_{\text {Supplied }} 110 \mathrm{mg}$ chlortetracycline, $110 \mathrm{mg}$ sulfamethazine and $55 \mathrm{mg}$ of penicillin per $\mathrm{kg}$ of feed.

choline was compared in trial 1 , and 0 vs 551 $\mathrm{mg} / \mathrm{kg}$ supplemental choline was compared in trial 2. The selected levels of choline supplementation were based upon previous recommendations by Kornegay and Meacham (1973). The level of choline in trial 2 was reduced because Stockland and Blaylock (1974) indicated that $412 \mathrm{mg} / \mathrm{kg}$ of supplemental choline was as effective as $824 \mathrm{mg} / \mathrm{kg}$. The gilts were fed once daily $2.04 \mathrm{~kg}$ in individual feeding stalls that did not allow gilts to be locked into the stalls. Before the initiation of the trial, gilts were fed a $16 \%$ crude protein sorghum-soybean meal diet with $551 \mathrm{mg} / \mathrm{kg}$ of supplemental choline.

Gilts were maintained in dirt lots and had fresh water available at all times. Portable housing was provided during winter and a shade with sprinklers was provided during the summer months.

Breeding was started about 1 wk after the gilts were placed on treatment. Gilts were checked daily for estrus and were hand mated to the same boar on two consecutive days. A 2 -mo breeding season was initiated on June 1 for trial 1 and December 1 for trial 2.

Gilts were fed a $16 \%$ crude protein lactation diet (diet D, table 1) once daily $(2.04 \mathrm{~kg} / \mathrm{d}$ ) from the time they were moved into individual farrowing stalls at $110 \mathrm{~d}$ of gestation. After parturition, gilts were allowed to consume the lactation diet ad libitum for the duration of the 42-d lactation period. All gilts were weighed at breeding, $110 \mathrm{~d}$ gestation and $42 \mathrm{~d}$ postpartum, when their litters were weaned. Pig weights were recorded at birth, 21 and $42 \mathrm{~d}$ of age. Pigs had access to creep feed from 21 to $42 \mathrm{~d}$.

All variables, with the exception of conception rate, were analyzed by least-squares procedures (SAS, 1979) and conception rate was analyzed using chi square procedures (Steel and Torrie, 1980). Pens were the main plot experimental units for comparing diets, and gilts within pens were the experimental units for comparing breed and breed $x$ diet interactions. The main plot analysis included the effects of trial $(T)$, protein level $(P)$, choline level $(\mathrm{C}), \mathrm{T} \times \mathrm{P}, \mathrm{T} \times \mathrm{C}, \mathrm{P} \times \mathrm{C}, \mathrm{T} \times \mathrm{P} \times \mathrm{C}$ interactions and pens within $\mathrm{T} \times \mathrm{P} \times \mathrm{C}$ subclasses. Pens within $T \times P \times C$ subclasses was the error for testing diet effects. The subplot analysis included the effects of breed $(B)$ and $B$ $\times \mathrm{T}, \mathrm{B} \times \mathrm{P}, \mathrm{B} \times \mathrm{C}$ and $\mathrm{B} \times \mathrm{T} \times \mathrm{P}$ interactions. The residual mean square was used for testing subplot effects. It was not the intent of the experiment to compare breeds, and breed $x$ diet interactions were not significant. Therefore, only the results of the main plot analysis will be presented.

\section{Results and Discussion}

Because there were no significant interactions between trial and dietary choline or protein for any of the variables measured, the pooled results of trials 1 and 2 are presented.

Diet effects on farrowing rate, gestation ga in and lactation gain are presented in table 2 . 
TABLE 2. EFFECT OF CHOLINE AND LEVEL OF PROTEIN ON CONCEPTION RATE AND WEIGHT GAIN OF GILTS

\begin{tabular}{|c|c|c|c|c|}
\hline \multirow[b]{2}{*}{ Item } & \multicolumn{2}{|c|}{ Choline } & \multicolumn{2}{|c|}{ Protein } \\
\hline & 0 & + & $12 \%$ & $16 \%$ \\
\hline $\begin{array}{l}\text { No. gilts } \\
\text { First-service conception rate }{ }^{\mathrm{a}}, \% \\
\text { Farrowing rate } \mathrm{b}, \% \\
\text { Wt at breeding, } \mathbf{k g} \\
\text { Gestation gain, } \mathrm{kg} \\
\text { Lactation gain, kg }\end{array}$ & $\begin{aligned} 109 & \\
72.4 & \\
86.2 & \\
127.9 & \pm 1.1 \\
44.8 & \pm 1.5 \\
-3.1 & \pm 2.0\end{aligned}$ & $\begin{array}{l}105 \\
68.6 \\
89.6 \\
127.7 \pm 1.1 \\
42.2 \pm 1.5 \\
-5.1 \pm 1.9\end{array}$ & $\begin{array}{l}109 \\
68.8 \\
86.2 \\
125.3 \pm 1.1 \\
42.4 \pm 1.5 \\
-2.9 \pm 2.0\end{array}$ & $\begin{aligned} 105 & \\
72.4 & \\
89.6 & \\
130.2 & \pm 1.1 \\
44.7 & \pm 1.5 \\
-5.3 & \pm 1.9\end{aligned}$ \\
\hline
\end{tabular}

${ }^{a}$ Gilts that farrowed a litter after one breeding period.

${ }^{b}$ Gilts that farrowed a litter of pigs.

$\mathrm{C}_{\text {Protein effect }(}(\mathrm{P}<.1)$.

Neither first-service conception rate nor overall farrowing rate was affected by level of dietary choline or protein supplementation. This response is consistent with the results of Kornegay and Meacham (1973), who observed no significant effect of choline on conception rate through six parities. Stockland and Blaylock (1974), however, reported a decrease in conception rate in gilts fed a corn-soybean meal diet with no supplemental choline.

Gestation and lactation gain was not affected by level of dietary choline or protein. These observations are consistent with the results of Stockland and Blaylock (1974), who observed no effect of choline on gestation gain. They are in contrast, however, to the finding of Grandhi and Strain (1981) who, in one trial, observed reduced gain in gilts fed supplemental choline, but found that choline had no effect on ga in in a second trial. Similar gestation gains have been reported for gilts fed a 12 or $16 \%$ protein (Holden et al., 1968) or a 13 or $17 \%$ protein (Mahan and Mangan, 1975) corn-soybean meal diet. The results of Haught et al. (1977) are consistent with our findings, suggesting that a $12 \%$ protein sorghum-soybean meal diet during gestation will support maximum gestation gain.

Neither litter size at birth, 21 or $42 \mathrm{~d}$, nor piglet survival rate to $42 \mathrm{~d}$ were affected $(P>.1)$ by dietary protein or choline level (table 3 ). The NCR-42 Committee on Swine Nutrition (1976) observed an increase in litter size of .5 pigs/litter for litters weaned at 2 wk of age. Grandhi and Strain (1981) reported an improvement in litter size at $5 \mathrm{wk}$ of .77 pigs for Lacombe gilts; Stockland and Blaylock (1974) reported an improvement of .60 pigs weaned for sows that received supplemental choline compared with sows that received the unsupplemental diet. Kornegay and Meacham (1973), however, failed to observe an effect of choline on litter size weaned, although choline supplementation increased litter size at birth. Grandhi and Strain (1981) observed no effect of choline on litter size weaned in Yorkshire gilts or in gilts fed supplemental choline during the summer months.

A consistent effect of both choline supplementation and protein level during gestation on subsequent pig and litter performance traits was evident (table 3 ). Gilts that received the diet with supplemental choline produced larger $(\mathrm{P}<.14)$ pigs at $42 \mathrm{~d}$ than gilts fed the unsupplemented control diet, and gilts fed the $16 \%$ protein diet produced larger $(\mathrm{P}<.13)$ pigs at 42 d than gilts fed the $12 \%$ protein diet. Similarly, litter weight was improved at $21 \mathrm{~d}(\mathrm{P}<.12)$ and $42 \mathrm{~d}(\mathrm{P}<.1)$ for gilts fed the supplemental choline diets ( 3.15 and $5.92 \mathrm{~kg}$, respectively) when compared with the unsupplemented control gilts. Gilts fed the $16 \%$ protein diet also had heavier litters at birth $(\mathrm{P}<.1), 21 \mathrm{~d}(\mathrm{P}<.14)$ and $42 \mathrm{~d}(\mathrm{P}<.05)$ than gilts fed the $12 \%$ protein diet.

The consistent improvement in litter performance traits as a result of increased choline in our study apparently is due to a slight but nonsignificant increase in number of pigs, as well as an improvement in pig weight. Previous researchers have consistently reported a choline effect on litter size (Kornegay and Meacham, 1973; Stockland and Blaylock, 1974; NCR-42 Committee on Swine Nutrition, 1978), although studies in which corn-based diets were used 
TABLE 3. THE EFFECT OF SUPPLEMENTAL CHOLINE AND LEVEL OF PROTEIN ON LITTER SIZE, SURVIVAL RATE AND PIG AND LITTER WEIGHT

\begin{tabular}{|c|c|c|c|}
\hline \multirow[b]{2}{*}{ Item } & \multicolumn{2}{|c|}{ Choline } & \multirow{2}{*}{$\begin{array}{l}\text { Protein main } \\
\text { effect }^{2}\end{array}$} \\
\hline & 0 & + & \\
\hline \multicolumn{4}{|l|}{ Litter size } \\
\hline \multicolumn{4}{|l|}{ Protein $12 \%$} \\
\hline No. born $b$ & $10.36 \pm .38$ & $10.78 \pm .37$ & $10.57 \pm .25$ \\
\hline No. at $21 \mathrm{~d}$ & $7.41 \pm .32$ & $8.08 \pm .31$ & $7.74 \pm .22$ \\
\hline No. at $42 \mathrm{~d}$ & $7.16 \pm .35$ & $7.81 \pm .32$ & $7.48 \pm .23$ \\
\hline Survival rate, \% & $68.71 \pm 3.1$ & $72.98 \pm 3.1$ & $70.8 \pm 1.9$ \\
\hline \multicolumn{4}{|l|}{ Protein $16 \%$} \\
\hline No. born & $10.94 \pm .32$ & $10.59 \pm .26$ & $10.77 \pm .25$ \\
\hline No. at $21 \mathrm{~d}$ & $8.12 \pm .28$ & $8.36 \pm .31$ & $8.24 \pm .22$ \\
\hline No. at $42 \mathrm{~d}$ & $7.87 \pm .28$ & $8.06 \pm .30$ & $7.96 \pm .22$ \\
\hline Survival rate, \% & $72.78 \pm 2.24$ & $76.13 \pm 2.34$ & $74.4 \pm 1.9$ \\
\hline \multicolumn{4}{|c|}{ Choline main effects $c$} \\
\hline No. born & $10.65 \pm .25$ & $10.69 \pm .25$ & \\
\hline No. at $21 \mathrm{~d}$ & $7.76 \pm .22$ & $8.22 \pm .22$ & \\
\hline No. at $42 \mathrm{~d}$ & $7.51 \pm .23$ & $7.93 \pm .22$ & \\
\hline Survival rate, $\%$ & $70.74 \pm 1.9$ & $74.64 \pm 1.9$ & \\
\hline \multicolumn{4}{|l|}{ Pig weight } \\
\hline \multicolumn{4}{|l|}{ Protein $12 \%$} \\
\hline Wt at birth, kg & $1.25 \pm .04$ & $1.25 \pm .02$ & $1.25 \pm .01$ \\
\hline Wt at $21 \mathrm{~d}, \mathrm{~kg}$ & $4.69 \pm .13$ & $4.84 \pm .13$ & $4.74 \pm .08$ \\
\hline Wt at $42 \mathrm{~d}, \mathrm{~kg}$ & $9.87 \pm .26$ & $10.04 \pm .22$ & $9.93 \pm .16^{\mathrm{d}}$ \\
\hline \multicolumn{4}{|l|}{ Protein $16 \%$} \\
\hline Wt at birth, kg & $1.25 \pm .03$ & $1.28 \pm .03$ & $1.26 \pm .01$ \\
\hline Wt at $21 \mathrm{~d}, \mathrm{~kg}$ & $4.69 \pm .11$ & $4.82 \pm .09$ & $4.74 \pm .08$ \\
\hline Wt at $42 \mathrm{~d}, \mathrm{~kg}$ & $9.99 \pm .21$ & $10.26 \pm .22$ & $10.11 \pm .16$ \\
\hline \multicolumn{4}{|c|}{ Choline main effects } \\
\hline Wt at birth, kg & $1.25 \pm .01$ & $1.27 \pm .01$ & \\
\hline Wt at $21 \mathrm{~d}, \mathrm{~kg}$ & $4.67 \pm .08$ & $4.81 \pm .08$ & \\
\hline Wt at $42 \mathrm{~d}, \mathrm{~kg}$ & $9.91 \pm .16^{\mathrm{e}}$ & $10.14 \pm .16$ & \\
\hline \multicolumn{4}{|l|}{ Litter weight } \\
\hline \multicolumn{4}{|l|}{ Protein $12 \%$} \\
\hline Wt at birth, kg & $12.77 \pm .48$ & $13.27 \pm .43$ & $12.99 \pm .10^{f}$ \\
\hline Wt at $21 \mathrm{~d}, \mathrm{~kg}$ & $34.78 \pm 1.71$ & $39.14 \pm 1.88$ & $36.87 \pm 1.26 \mathrm{~g}$ \\
\hline Wt at $42 \mathrm{~d}, \mathrm{~kg}$ & $70.68 \pm 3.68$ & $78.40 \pm 3.40$ & $74.38 \pm 2.56^{h}$ \\
\hline \multicolumn{4}{|l|}{ Protein $16 \%$} \\
\hline Wt at birth, kg & $13.63 \pm .46$ & $13.45 \pm .45$ & $13.51 \pm .10$ \\
\hline Wt at $21 \mathrm{~d}, \mathrm{~kg}$ & $38.45 \pm 1.73$ & $40.41 \pm 1.68$ & $39.34 \pm 1.24$ \\
\hline Wt at $42 \mathrm{~d}, \mathrm{~kg}$ & $78.08 \pm 3.66$ & $82.22 \pm 3.39$ & $80.16 \pm 2.51$ \\
\hline \multicolumn{4}{|c|}{ Choline main effects } \\
\hline Wt at birth, kg & $13.17 \pm .10$ & $13.33 \pm .10$ & \\
\hline Wt at $21 \mathrm{~d}, \mathrm{~kg}$ & $36.53 \pm 1.24^{\mathrm{i}}$ & $39.68 \pm 1.25$ & \\
\hline Wt at $42 \mathrm{~d}, \mathrm{~kg}$ & $74.22 \pm 2.56^{\mathrm{ij}}$ & $80.14 \pm 2.51$ & \\
\hline
\end{tabular}

${ }^{a}$ A total of 94 and 95 gilts for the 12 and $16 \%$ protein treatments, respectively, was utilized in this study.

${ }^{b}$ Number of fully formed pigs.

${ }^{c}$ A total of 93 and 96 gilts for the 0 choline and + choline treatments, respectively, was utilized in this study.

$\mathrm{d}_{\text {Protein main effect }(}(\mathrm{P}<.13)$.

e Choline main effect $(P<.14)$.

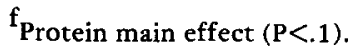

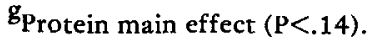

$\left.h_{\text {Protein main effect }(}<<.05\right)$.

${ }^{i}$ Choline main effect $(P<.12)$.

$\mathrm{j}_{\text {Choline main effect }}(\mathrm{P}<.1)$. 
(Grandhi and Strain, 1981), did not show any improvement in weaning weight due to increased gestation choline levels.

Dietary protein and methionine have been shown to spare completely choline for growth (Nesheim et al., 1949; Dyer and Krider, 1950; Firth et al., 1953; Kroening and Pond, 1967; Bryant et al., 1977; Russett et al., 1979b), and the increase in choline from soybean meal in the high protein diet increased dietary choline (865 vs $1,105 \mathrm{mg} / \mathrm{kg}$ for the low and high protein diets, respectively). Our data suggest that the choline effect was more evident in gilts fed a $12 \%$ protein diet than gilts fed a $16 \%$ protein diet, and that the effect was most evident at $42 \mathrm{~d}$ postpartum (table 3 ). Choline supplementation consistently had a greater effect in gilts fed a $12 \%$ protein diet than in those that were fed the $16 \%$ protein diet, although the protein $x$ choline interaction was not significant for any traits measured. The increase in litter size at $\mathbf{2 1}$ and $\mathbf{4 2} \mathrm{d}$ for gilts fed supplemental choline compared with the unsupplemental control was greater for gilts fed the $12 \%$ diet $(.68$ and .65 for 21 and $42 \mathrm{~d}$, respectively) than for those fed the $16 \%$ diet (.24 and .19 for 21 and $42 \mathrm{~d}$, respectively). Similarly, a trend for a larger choline effect on pig and litter weight was observed in gilts fed the $12 \%$ protein diet than for those fed the $16 \%$ protein diet. The high level of choline increased litter weight at 21 and $42 \mathrm{~d}$ by 4.36 and $7.72 \mathrm{~kg}$, respectively, for gilts fed the $12 \%$ protein diet; whereas the high level of choline increased litter weights by only 1.9 and $4.2 \mathrm{~kg}$ at 21 and $42 \mathrm{~d}$, respectively, in gilts that received the $16 \%$ protein diet. Our data suggest that, unlike the situation with growing pigs, the higher level of protein, methionine and(or) choline in gilts fed the $16 \%$ protein gestation diet only partially spared supplemented choline. Previous investigatiors have consistently observed an improvement in litter size in gestating swine fed $15 \%$ protein diets supplemented with choline (Kornegay and Meacham, 1973; Stockland and Blaylock, 1974; NCR-41 Committee on Swine Nutrition, 1976; Grandhi and Strain, 1981). Our data suggest that the choline effect on reproductive performance may be even greater in swine fed a lower protein level during gestation.

The effect of dietary protein during gestation in swine fed corn-based diets has been extensively studied. Many investigators (Baker et al., 1970a,b; Hesby et al., 1970, 1972;
Hawton and Meade, 1971) have demonstrated satisfactory gestation in swine fed a fortified corn diet. Likewise, the effect of gestation diets almost devoid of protein (Pond et al., 1968, 1969; DeGeeter et al., 1972; Shields et al., 1980) have had only small effects on gestation performance. It is evident that the dam can utilize tissue resources of amino acids for the developing fetus (Shields et al., 1985). Less clearly defined, however, is the carry-over effect of low gestation protein levels on subsequent lactation performance of the dam. It has been clearly demonstrated that fortified, corn-based gestation diets resulted in decreased postpartum performance even though lactation diets met or exceeded NRC (1979) requirements (Rippel et al., 1965; Baker et al., 1970a,b; Hawton and Meade, 1971; Hesby et al., 1972; Mahan, 1977). Mahan and Grifo (1975) observed a linear increase in pig weight gain with increasing dietary lactation protein levels from 12 to $18 \%$ when the dam had received a viramin-and mineral-fortified corn diet during gestation. Mahan and Mangan (1975) have further demonstrated an interactive effect on progeny performance in gilts fed either 9,13 or $17 \%$ protein diets during gestation and 12 or $18 \%$ protein diets during lactation. Their results suggest that, if adequate or surplus protein is supplied in the lactation diet, litter gain would not be affected by dietary protein level, but if lactating swine are fed an inadequate lactation diet, previous gestation treatment becomes an important factor in subsequent litter performance. This response is consistent with the observations of the NCR-42 Committee on Swine Nutrition (1978), which observed a reduction in pig weight and gain at $14 \mathrm{~d}$ of age when a $9 \%$ protein gestation diet was used in combination with a $12 \%$ lactation protein level. No differences were observed when a minimum of $16 \%$ protein was fed during lactation, irrespective of gestation protein level. In contrast to these results, our studies suggest that a $16 \%$ protein sorghum-soybean meal diet during lactation was not sufficient to overcome the effect of feeding a $12 \%$ protein sorghumsoybean meal diet during gestation. The results of our studies suggest that the gestation protein requirement to ensure maximum reproductive performance in sows fed sorghum-soybean meal diets and an adequate protein diet during lactation may be higher than $12 \%$. Other researchers using corn-soybean meal-based diets (Baker et al., 1970a; Mahan, 1979; Haye et al., 
TABLE 4. THE EFFECT OF PROTEIN AND CHOLINE ON THE SPRADDLE LEG CONDITION IN NEW BORN PIGS

\begin{tabular}{|c|c|c|c|c|}
\hline \multirow[b]{2}{*}{ Item } & \multicolumn{2}{|c|}{ Choline } & \multicolumn{2}{|c|}{ Protein } \\
\hline & 0 & + & $12 \%$ & $16 \%$ \\
\hline No. gilts farrowing & 94 & 94 & 94 & 94 \\
\hline \multicolumn{5}{|l|}{ No. litter with one or more pigs } \\
\hline with spraddle legs & 8 & 10 & 12 & 6 \\
\hline No. live pigs farrowed with spraddle legs & 11 & 12 & 13 & 10 \\
\hline
\end{tabular}

1981) have reported that a $12 \%$ protein gestation diet is sufficient for optimum reproductive performance.

The incidence of spraddle leg condition was low and was not affected by level of dietary choline or protein (table 4). Although these findings were in contrast with the suggestions of Cunha (1968), they are consistent with the observation of Stockland and Blaylock (1974), NCR-42 Committee on Swine Nutrition (1976) and Grandhi and Strain (1981), who observed no effect of choline on the number of spraddle leg pigs. Likewise, Dodson (1971) was unable to prevent the spraddle leg condition with either choline or methionine supplementation.

The lack of significant replicate $x$ choline interaction for any variable provides evidence that the lower level of supplemental choline used in trial $2(551 \mathrm{mg} / \mathrm{kg})$ was as effective as the higher level of choline used in trial 1 (882 $\mathrm{mg} / \mathrm{kg}$ ). Stockland and Blaylock (1974), using corn-soybean meal diets, indicated that $412 \mathrm{mg}$ of supplemental choline was equally as effective as $824 \mathrm{mg} / \mathrm{kg}$.

\section{Literature Cited}

Baker, D. H., D. E. Becker, A. H. Jensen and B. G. Harmon. 1970a. Protein source and level for pregnant gilts: A comparison of corn, opaque-2 corn and corn-soybean meal diets. J. Anim. Sci. 30: 364 .

Baker, D. H., D. E. Becker, A. H. Jensen and B. G. Harmon. 1970b. Reproductive performance and progeny development in swine as influenced by protein restriction during various portions of gestation. J. Anim. Sci. 31:526.

Bryant, K. L., G. E. Combs and H. D. Wallace. 1977. Supplemental choline for young and growingfinishing swine. Res. Rep: 22nd Annu. Swine Field Day, Univ. of Florida, Gainesville.

Cousins, B. W., T. D. Tanksley, Jr., D. A. Knabe and Teresa Zebrowska. 1981. Nutrient digestibility and performance of pigs fed sorghums varying in tannin concentration. J. Anim. Sci. 53:1524.
Cunha, T. J. 1968. Spradle hind legs may be a result of choline deficiency. Feestuffs $40(10): 25$.

DeGeeter, M. J., V. W. Hays, D. D. Kratzer and G. L. Cromwell. 1972. Reproductive performance of gilts fed diets low in protein during gestation and lactation. J. Anim. Sci. 35:772.

Dodson, K. J. 1971. Failure of choline and methionine to prevent spraddle leg in piglets. Australian Vet. J. $47: 587$.

Dyer, I. A. and J. L. Krider. 1950. Choline versus betaine and expeller versus solvent soybean meal for weanling pigs. J. Anim. Sci. 9:176.

Easter, R. A. 1972. Availability of selected amino acids in sorghum grain and corn determined in ileocecal cannulated finishing pigs. M. S. Thesis. Texas A \& M Univ., College Station.

Firth, J. M., James, I. Chang, S. P. Mistry and B. C. Johnson. 1953. Vitamin $B_{12}$ and choline synthesis in the baby pig. J. Anim. Sci. 12:915 (Abstr.).

Grandhi, R. R. and J. H. Strain. 1981. Choline supplementation of barley-wheat-soya diets and the reproductive performance of swine. Can. J. Anim. Sci. $61: 803$.

Haught, D. G., T. D. Tanksley, Jr., J. H. Hesby and E. J. Gregg. 1977. Effect of protein level, protein restriction and cottonseed meal in sorghum-based diets on swine reproduction performance and progeny development. J. Anim. Sci. 44:249.

Hawton, J. D. and R. J. Meade. 1971. Influence of quantity and quality of protein fed the gravid female on reproductive performance and development of offspring in swine. J. Anim. Sci. 32:88.

Haye, S. N., E. T. Kornegay and D. C. Mahan. 1981. Antibody response and serum protein and immunoglobulin concentrations in pigs from sows fed different protein sequences during gestation and lactation. J. Anim. Sci. 53:1262.

Hesby, J. H., J. H. Conrad, M. P. Plumlee and R. B. Harrington. 1972. Effects of normal corn, normal corn plus lysine and opaque- 2 corn diets on serum protein and reproductive performance of gravid swine. J. Anim. Sci. 34:974.

Hesby, J. H., J. H. Conrad, M. P. Plumlee and T. C. Martin. 1970. Normal corn, opaque 2-corn and corn-soybean meal for swine reproduction. J. Anim. Sci. 31:474.

Holden, P. J., E. W. Lucas, V. C. Speer and V. W. Hays. 1968. Effect of protein level during pregnancy and lactation on reproductive performance in swine. J. Anim. Sci. 27:1587.

Kornegay, E. T. and T. N. Meacham. 1973. Evaluation 
of supplemental choline for reproducing sows housed in total confinement on concrete or in dirt lots. J. Anim. Sci. 37:506.

Kroening, G. H. and W. G. Pond. 1967. Methionine, choline and threonine interrelationships for growth and lipothropic action in the baby pig and rat. J. Anim. Sci. 26:352.

Mahan, D. C. 1977. Effect of feeding various gestation and lactation dietary protein sequences on long-term reproductive performance in swine. $\mathrm{J}$. Anim. Sci. 45:1061.

Mahan, D. C. 1979. Effect of dietary protein sequence on long-term sow reproductive performance. $\mathrm{J}$. Anim. Sci. 49:514.

Mahan, D. C. and A. P. Grifo, Jr. 1975. Effects of dietary protein levels during lactation to first litter sows fed a fortified corn gestation diet. J. Anim. Sci. 41:1362.

Mahan, D. C. and L. T. Mangan. 1975. Evaluation of various protein sequences on the nutritional carry-over from gestation to lactation with first-litter sows. J. Nutr. 105:1291.

NCR-42 Committee on Swine Nutrition. 1976. Effect of supplemental choline on reproductive performance of sows: A cooperative regional study. $\mathrm{J}$. Anim. Sci. 42:1211.

NCR-42. Committee on Swine Nutrition. 1978. Effect of protein level during gestation and lactation on reproductive performance in swine. J. Anim. Sci. 46:1673.

Nesheim, R. O., J. L. Krider and B. C. Johnson. 1949. The effect of a high level of methionine on the choline requirement of the baby pig. J. Anim. Sci. 8:627 (Abstr.).

NRC. 1979. Nutrient Requirements of Domestic Animals, No. 2. Nutrient Requirements of Swine. Eighth Revised Ed. National Academy of Sciences-National Research Council, Washington,
DC.

Pond, W. G., D. N. Strachan, Y. N. Sinha, E. G. Walker, Jr., J. A. Dunn and R. H. Barnes. 1969. Effect of protein deprivation of swine during all or part of gestation on birth weight, postnatal growth weight and nucleic acid content of brain and muscle of progeny. J. Nutr. 99:61.

Pond, W. G., W. C. Wagner, J. A. Dunn and E. F. Walker, Jr. 1968. Reproduction and early postnatal growth of progeny in swine fed a proteinfree diet during gestation. J. Nutr. 94:309.

Rippel, R. H., O. G. Rasmussen, A. H. Jensen, H. W. Norton and D. E. Becker. 1965. Effect of level and source of protein on reproductive performance in swine. J. Anim. Sci. 24:203.

Russett, J. C., J. L. Krider, T. R. Cline, H. L. Thatcher and L. B. Underwood. 1979a. Choline-methionine interactions in young swine. J. Anim. Sci. 49:708.

Russett, J. C., J. L. Krider, T. R. Cline and L. B. Underwood. 1979b. Choline requirement of young swine. J. Anim. Sci. 48:1366.

SAS. 1979. SAS User's Guide. Statistical Analysis System Institute, Inc., Cary, NC.

Shields, R. G., Jr., D. C. Mahan and K. E. Ekstrom.

1980. Effect of moderate or severe protein restriction during pregnancy on sow and progeny digestive enzymes. J. Nutr. 110:1507.

Shields, R. G., Jr., D. C. Mahan and P. F. Maxon. 1985. Effect of dietary gestation and lactation protein levels on reproductive performance and body composition of first litter female swine. $J$. Anim. Sci. 60:179.

Steel, R.G.D. and J. H. Torrie. 1960. Principles and Procedures of Statistics. McGraw-Hill Book Co., New York.

Stockland, W. L. and L. G. Blaylock. 1974. Choline requirement of pregnant gilts under restricted feeding conditions. J. Anim. Sci. 39:1113. 